有機発光素子における界面の問題*

時 任 静 士*1

\title{
Issue of Interfaces in Organic Light-Emitting Diodes
}

Shizuo TOKITO

NHK Science and Technology Research Laboratories 1-10-11, Kinuta, Setagaya-ku, Tokyo 157-8510, Japan

(Received Augus 17, 2009, Accepted September 11, 2009)

\begin{abstract}
Organic light-emitting diodes involve several interfaces such as metal/organic, inorganic/organic and organic/organic layers. These interfaces significantly influence the performances, efficiency and lifetime, of the light-emitting diode. In this article, potential barriers for electrons and holes at the interfaces are discussed to control the charge injection and confinement. Insertion of a thin interlayer and doping of a donor or an acceptor into the organic layers at the interfaces reduce the potential barriers.
\end{abstract}

\section{1. はじめに}

非常に薄い有機薄膜に電流を流すことで発光する有機電界 発光（EL）素子は液晶ディスプレイやプラズマディスプレ イに続く次世代のフラットパネルディスプレイとして注目さ れ，すでに携帯電話やデジタルカメラ，さらには小型テレビ などに拈いて着実に実用化が進められている1-3)。また，環 境問題とも絡み省電力な固体照明への応用でも期待されてい る4). 有機 $\mathrm{EL}$ 素子の基本構造は発光層を院極と陽極で挟ん だ単純な単層であるが，実用的な素子においては，高い発光 効率と信頼性の確保の観点から Fig 1 に示すような多層構 造がとられている. 複雑なものでは陽極上に, 正孔注入層 (HIL), 正孔輸送層 (HTL), 発光層 (EML), 電子輸送層 (ETL), 電子注入層 (EIL) が重ねられ, 最後に金属電極が 形成された 5 層構成となっている. そのため, 酸化物電極 と有機薄膜, 有機薄膜と有機薄膜, 有機薄膜と金属電極とい った多数の界面を含むことになる.これら界面は素子の発光 効率や信頼性等を大きく左右する. 界面の抱える問題を十分 に理解し, 制御することが有機 EL 素子の高性能化に必要で あることは言うまでもない。

最近の有機 EL 素子は開口率の改善, 高効率化, 長寿命化 の観点から，さらに複雑な構造をとるようになってきた．陽 極側と陰極側が逆転した構造や陰極に透明金属酸化物を用い る構造などもある. 本稿では, 混乱を避けるために主として 代表的な 2 層構造に限定し, 陽極/有機, 金属/有機, 有機/ 有機の界面制御の研究動向について筆者らの研究成果や経験 的な知見を基に述べることにする. 特に, 界面での正孔や電 子移動に関係する電位障壁の問題を中心に述べる．有機 EL 素子が抱える界面の重要性について少しでも理解して頂けれ ば幸いである。

\section{2. 陽極/有機界面}

正孔輸送層と発光層からなる 2 層型のエネルギー構造を 模式的に描くとすると Fig. 2 のようになる. 代表的な正孔

\footnotetext{
* 平成 21 年 2 月 24 日 日本真空協会 2009 年 2 月研究例会 ·日本 表面科学会第61回表面科学研究会で発表

*1 NHK 放送技術研究所
}

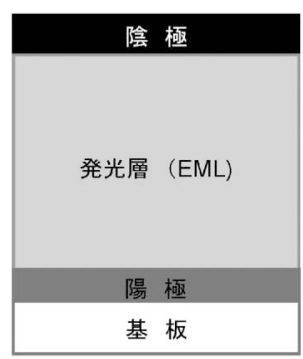

(a) 単層

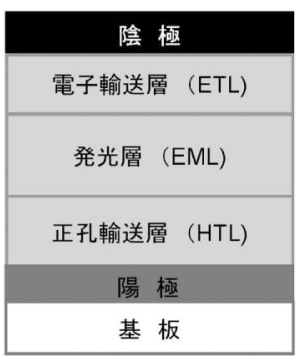

(c) 3層

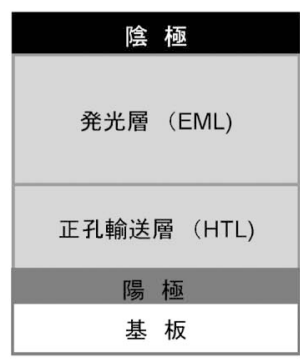

(b) 2層

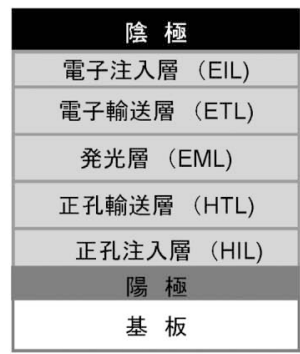

(d) 5 層
Fig. 1 Schematic structure of organic light-emitting diodes; (a) single layer, (b) two-layer, (c) three-layer, and (d) fivelayer structure.

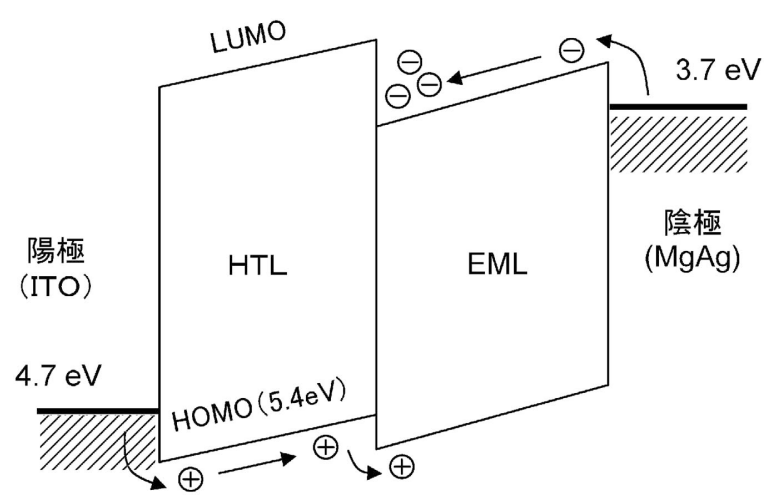

Fig. 2 Energy diagram for a two-layer OLED consisting of hole transporting layer and emitting layer. Anode and cathode are ITO and $\mathrm{MgAg}$, respectively. 


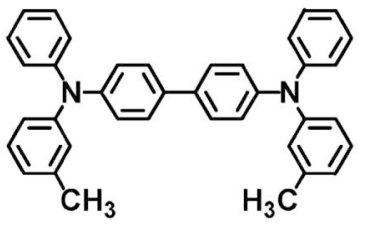

TPD

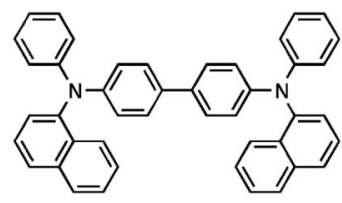

$\alpha-N P D$

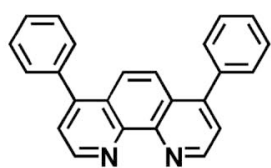

$\mathrm{BCP}$

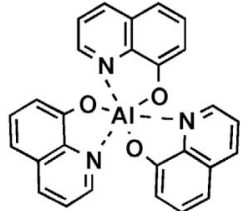

$\mathrm{Alq}_{3}$

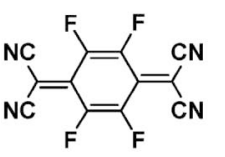

$\mathrm{F}_{4}-\mathrm{TCNQ}$

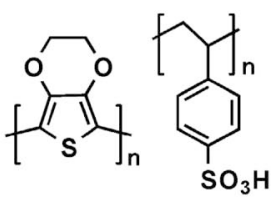

PEDOT:PSS
Fig. 3 Molecular structures of several organic materials used in OLED devices.

輸送材料としては芳香族アミンの $\alpha-\mathrm{NPD}$ ，発光層としては 金属錯体の $\mathrm{Alq}_{3}$ がある1)。参考として，本稿で取り上げる いくつかの材料の分子構造を Fig. 3 に示す. この素子に外 部から直流電圧を印加すると電流が流れるが，このとき陽極 からは正孔が注入され, 正孔輸送層の電子が満ちた分子軌道 （最高占有分子軌道：HOMO）を移動する. 一方，陰極側か らは電子が発光層へ注入される. 薄膜中を輸送された正孔と 電子は正孔輸送層と接する発光層側で再結合し発光に寄与す る.そのため, 単純に考えれば陽極のフェルミ準位（仕事関 数に相当）と正孔輸送層の HOMO 準位との差が正孔に対す る電位障壁となる. 最も広く使用されている陽極は酸化イン ジウム錫（ITO）であり，その仕事関数は $4.7 \mathrm{eV}$ 程度であ る. 一方, 正孔輸送層の HOMO は $5.4 \mathrm{eV}$ 程度が代表的であ るため, 単純には $0.7 \mathrm{eV}$ の電位障壁となるが, 実際は界面 での複雑な現象のため正確な障壁は実測が難しい。たとえ ば，接合による電荷移動によって形成される界面双極子が真 空準位のシフトなどを引き起こす5)。いずれせよ，多くの場 合, ITO と有機層の界面には電位障壁が存在する．この障 壁の存在は動作電圧の上昇を招くことになり，余分なシュュー ル熱や界面での高電界の発生により素子寿命を短くすること になる. また, 重要な発光効率である電力効率は動作電圧に 逆比例する次式で表される.

$$
\eta_{p} \propto \eta_{\text {ext }} V_{\lambda} / V
$$

ここで, $\eta_{\text {ext }}$ は外部量子効率, $V_{\lambda}$ は発光ピーク波長の光エ ネルギー $(\mathrm{eV}), V$ は動作電圧 $(\mathrm{V})$ である.つまり, 動作 電圧が低下するほど電力効率は向上することになる，消費電 力の低減から言えば，動作電圧が低いほど好ましい。

初期の研究では，この電位障壁を低減するために HOMO 準位が浅い正孔注入層を挿入する手法がとられている. 例え ば，銅フタロシアニン6)やスターバーストアミン7)が正孔注

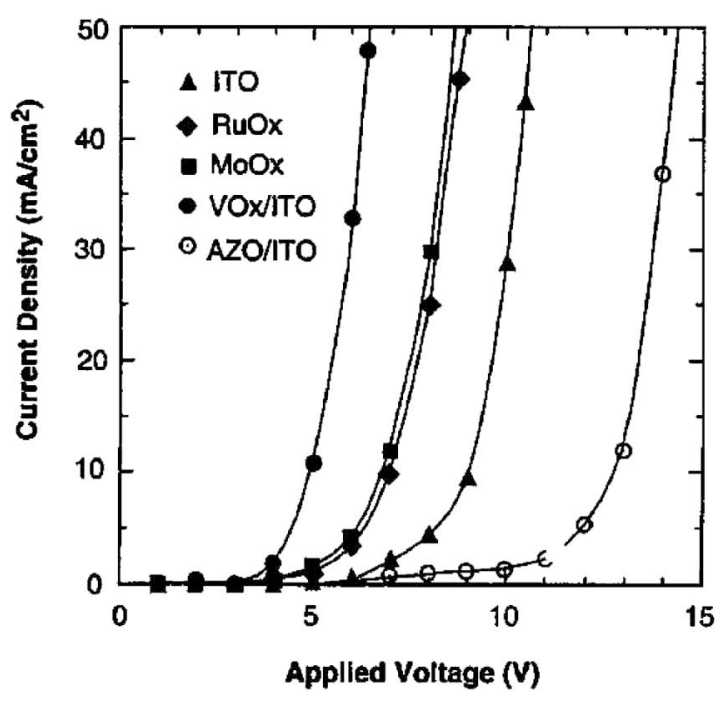

(a)

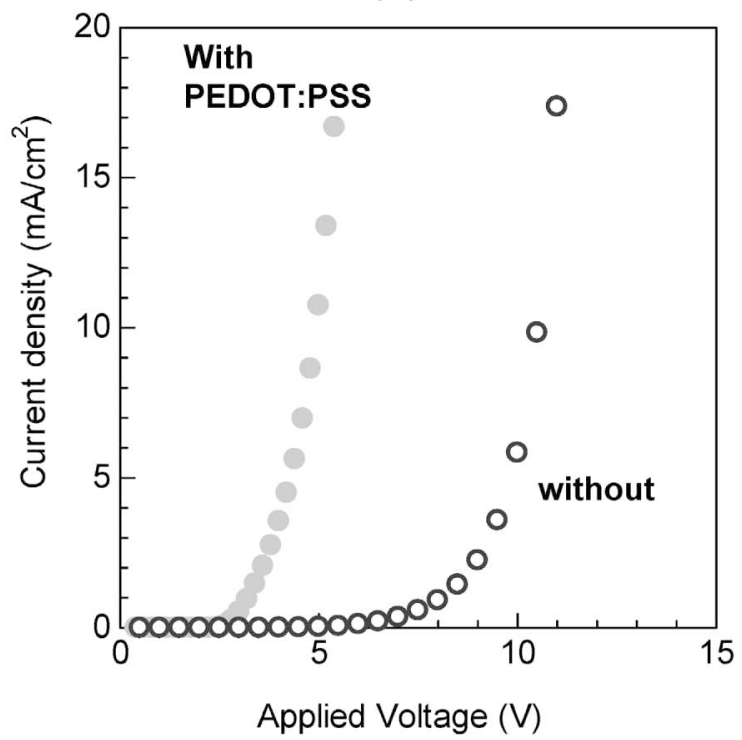

(b)

Fig. 4 Current-voltage characteristics of OLEDs with (a) metal oxides layer and (b) PEDOT: PSS as the hole injection layer.

入層として用いられた。これらは HOMO 準位が $5.0 \mathrm{eV}$ 程度 であるため，ITO と正孔輸送層の中間的な值である。ま た，プラズマ放電で極薄い炭素系薄膜を形成する方法なども 用いられている8). 筆者は, ITO 表面に金属酸化物を薄く成 膜することで正孔注入を改善することを試みた ${ }^{9)}$ 。具体的に は，スパッタ成膜法を用いて十数種類の金属酸化物を検討し た結果，3種類でその効果を見出した. 酸化モリブデン $(\mathrm{MoOx})$ ，酸化バナジウム $(\mathrm{VoOx})$ や酸化ルテニウム (RuOx) がその代表例である.いずれの薄膜も高抵抗の半 導体的な電気伝導度を有し，光透過率も優れている。これら 金属酸化物薄膜を ITO 側に用いた正孔輸送層と発光層の 2 層型有機 EL 素子の結果を Fig. 4(a) に示す.ここでの正孔 輸送層には TPD を用いている. 注入電流の大幅な増大が観 測され, 明らかに正孔注入が改善されていることを分かる. 発光開始電圧と金属酸化物の仕事関数の間に明瞭な相関性が 認められ，仕事関数が大きいことが正孔注入を促進している 
と理解できる.この材料の有効性を見出してから十数年経過 しているが, 最近, 多くの研究者がこの材料に注目してくれ ている. 電位障壁低下の原因に関連する $\mathrm{MoOx}$ と有機分子 の電子的相互作用が紫外光電子分光法 (UPS) や可視吸収 スペクトル, レーザーラマン分光法で観測されて打り, 研究 が活発化している.

導電性高分子を正孔注入層に用いる例も一般的である. 代 表的な導電性高分子はポリエチレンジオキシチオフェン: ポ リスルフォン酸（PEDOT:PSS）で, 元来は高分子 EL 素 子の正孔注入層に用いられている ${ }^{10)}$ 。この他に芳香族アミ ン系高分子にルイス酸などをドープした導電性高分子も開発 されている. Fig. 4 (b) は $\alpha$-NPD と $\mathrm{Alq}_{3}$ の 2 層型素子に PEDOT : PSS を $30 \mathrm{~nm}$ ほど挿入した場合の特性である。 ITO から直接に $\alpha-\mathrm{NPD} に$ 正孔を注入するよりは, PEDOT : PSS を介した方が正孔を注入し易くなっている. PEDOT : PSS の仕事関数は約 $5.0 \mathrm{eV}$ 付近にあり, ITO と $\alpha-\mathrm{NPD}$ の中間的な值に位置する.

最近では, 強い電子受容性の分子を陽極側の正孔輸送層に ドープして高導電性にすることで注入障壁を低下させる方法 が盛んに用いられるようになってきた. 正孔輸送材料と電子 受容性分子を同時に真空蒸着することでドープ層（混合層） を形成する。その比率は $1: 1$ と非常に高濃度である。この ドーピングによって多数のカチオンラジカルが正孔輸送層内 に生成し, 高い導電性を発現する. 電子受容性分子の代表例 が $\mathrm{F}_{4}-\mathrm{TCNQ}$ である ${ }^{11)}$. 正孔輸送層である $\alpha-\mathrm{NPD}$ の約 5 nm だけに $\mathrm{F}_{4}-\mathrm{TCNQ}$ をドープした場合の特性を Fig. 5 に 示す. 明らかな注入電流の増大が観測される. また, 前述し た金属酸化物なども電子受容性ドーパントとして効果的であ る. 特に, $\mathrm{MoOx}$ は有用な材料として急速にその利用が広 まっている.

以上のように, 界面に正孔注入を促進する薄い有機層ある は無機層を㨂入する方法や電子受容性ドーパントを正孔輸送 層にドープすることでの界面制御が行われている.

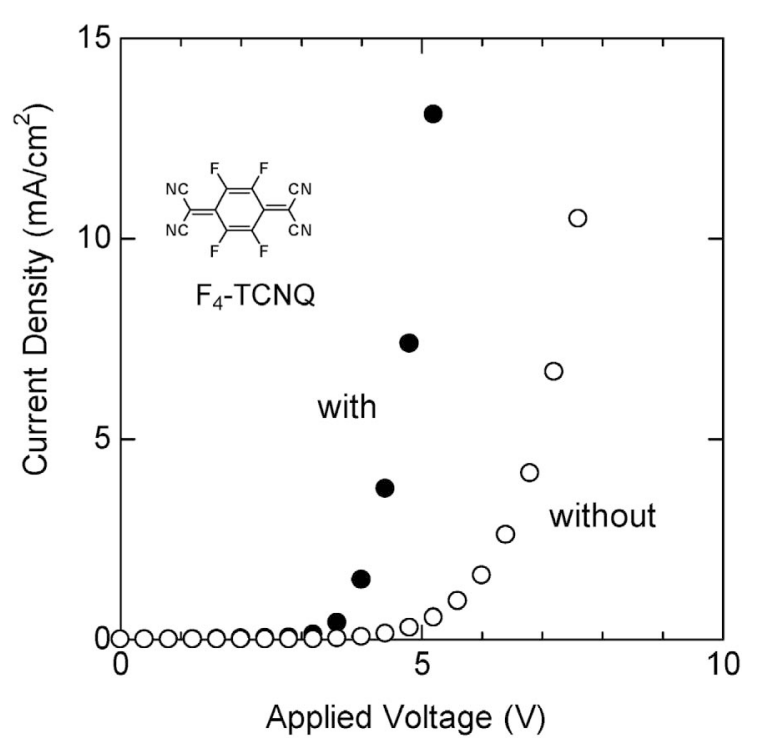

Fig. 5 Current-voltage characteristics of an OLED with a hole transport layer doped with $\mathrm{F}_{4}-\mathrm{TCNQ}$. Thickness of the doped region is about $5 \mathrm{~nm}$.

\section{4. 陰極/有機界面}

陰極からは発光層あるいは電子輸送層の最低被占有分子軌 道（LUMO）準位へ電子が注入される. 陰極側も陽極側と 同様に電位障壁が存在するため, これを低減させる必要が る. 極力 LUMO 準位の深い電子輸送材料や電子注入材料を 選択する必要がある. 院極材料としては仕事関数の小さなも のの方が電位障壁を小さくできるため, 初期には $\mathrm{MgAg}$ 合 金が用いられたが，その後はより安定な $\mathrm{Al}$ が用いられるよ うになった，但し， $\mathrm{Al}$ の仕事関数は $4.2 \mathrm{eV}$ とかなり大きい ため電子注入には不適である. そこで, 界面に $\mathrm{Li}_{2} \mathrm{O}_{3}$ や $\mathrm{LiF}$ などの酸化物やフッ化物を非常に薄く插入することで大幅な 注入障壁低下が実現できている ${ }^{12,13)}$. LiF の効果を Fig. 6 (a)に示す． $\alpha-\mathrm{NPD}$ と $\mathrm{Alq}_{3}$ の 2 層型素子での結果である. $\mathrm{Al}$ だけの場合, 動作電圧が高いが, $\mathrm{LiF}$ の挿入で明確な電

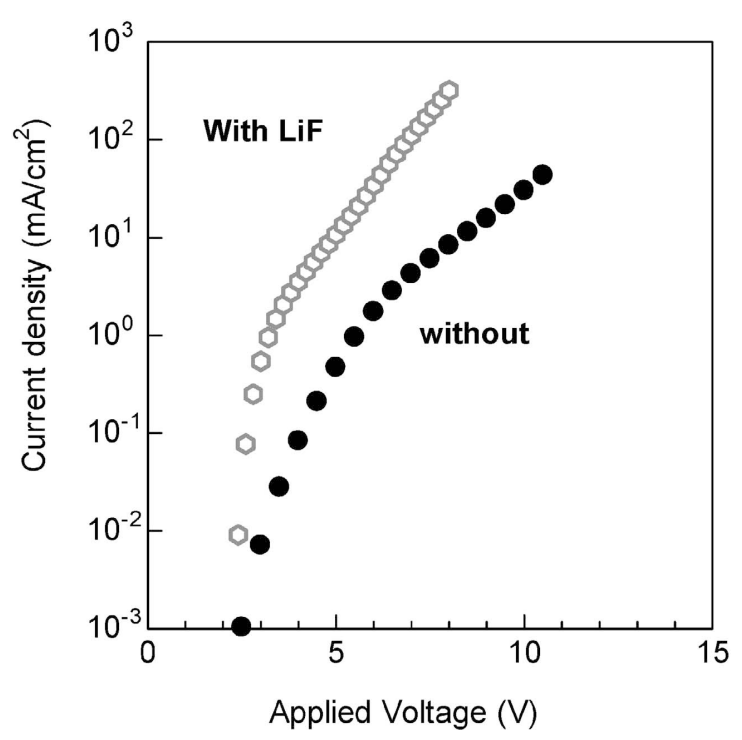

(a)

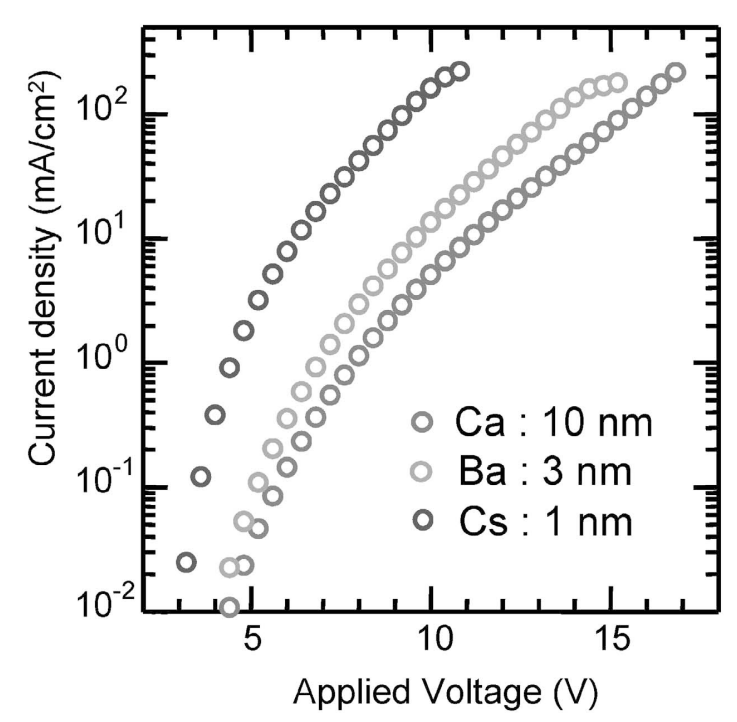

(b)

Fig. 6 Current-voltage characteristics of a two-layer OLED with a LiF thin layer, and (b) a phosphorescent OLED with a thin metal layer between organic layer and $\mathrm{Al}$ cathode. 
圧低下が観測される。その理由は，いまだ明確ではないが， 脱離した Li がドーパントとして効いている, あるは， LiF 層が界面双極子を形成して真空準位を低下させているなどが 報告されている. また, Fig. 6(b)のリン光性高分子を発光 層に用いた素子の場合は, $\mathrm{Ca}, \mathrm{Ba}, \mathrm{Cs}$ の順で, 仕事関数が 小さい金属ほど電子注入が促進されている14). 実効的な電 位障壁が低下していることになり, 大まかには仕事関数の值 で説明できる.しかし，発光層への拡散によるドーピング効 果も否定できない.

一般に, 陰極形成は有機層上への真空蒸着法で行うため, 有機層への電極金属の拡散や, 化学反応の可能性が指摘され ている. 化学反応については, 分子自体を分解させる化学反 応ではなく，前述したように金属原子が電子供与性ドーパン トとして有機分子に配位する. その電子的相互作用は前述し たように可視吸収スペクトルでも観測することができる. 最 近では陽極側と同じように積極的に界面層にドープして電位 障壁を低減する方法がとられるようになってきた，この場 合, 電子供与性のドーパントで, 電子輸送層内にラジカルア ニオンを生成して高導電性となる. 初期の例としては, 電子 輸送層である $\mathrm{Alq}_{3}$ に Li をドープしている15). その後, BCP にCs をドープする例が報告されている，最近では，陽極側 と陰極側にそれぞれ電子受容性ドーパントのドープ層 $(\mathrm{P}$ 層) と電子供与性ドーパントのドープ層 $(\mathrm{N}$ 層) を設けた $\mathrm{PIN}$ 構造が広く用いられるようになっている16). Novaledのグ ループが報告している例としては, Fig. 7 に示すように $\mathrm{P}$ 層は $\mathrm{F}_{4}-\mathrm{TCNQ}$ をドープした m-MTDAT 層で, N 層は Cs をドープした BCP 層である. I 層はドープしていない発光 層と正孔輸送層である. 当初, ドープ層の導入は安定性が心 配されたが，予想外に大幅な寿命向上が実現できている.

一般に, 有機 EL 素子の発光はガラス基板側の ITO を通 して外部へ取り出される.このような従来構造をボトムエミ ッシン構造と呼ぶ. しかし, 実際のディスプレイでは開口率 を大幅に高めることができる上部陰極側から光を取り出すト ップエミッション構造が好ましい.この場合, 上部電極とし

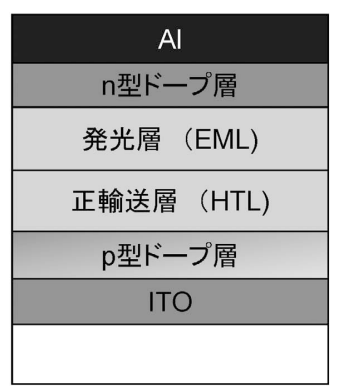

$M:$ 有機分子

$D$ ：電子供与性ドーパント

A : 電子受容性ドーパント
$\mathbf{M}^{-}: \mathbf{D}^{+}$

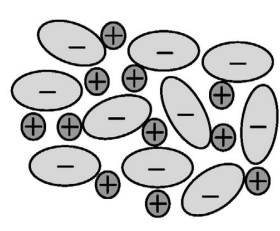

$\mathbf{M}^{+}: \mathbf{A}^{-}$

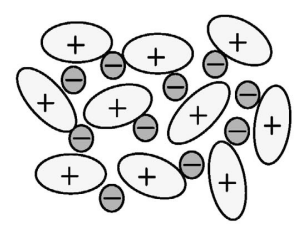

Fig. 7 Schematic device structure with PIN structure. P layer is doped with an acceptor, $\mathrm{N}$ layer is doped with a donor.
て透明な ITO などを用いることになるが，ITO の仕事関数 が大きいため電子注入は困難である. そのためITO と電子 輸送層の間に薄い $\mathrm{Mg}$ などを挿入することで電子注入を改 善している ${ }^{24)}$. この薄い $\mathrm{Mg}$ 層の形成は電子注入だけでな く ITOをスパッタ成膜する際のプラズマ中のイオンや 2 次 電子で電子輸送層が損傷するのを回避する役割も果している.

\section{5. 有機/有機界面}

前述したように有機 EL 素子には有機層と有機層の界面を 多数含む. 電子輸送層/発光層, 発光層/電子輸送層なぞがそ の代表例である。一般には, 界面にHOMOあるいは LUMO の電位障壁を設けて, 注入された電子や正孔の素子 内での流れを制御する狙いがある. 例えば, Fig. 2 にも示し たように正孔輸送層と発光層の界面では HOMO 側の電子障 壁をなるべく小さくして正孔注入を容易にし, 逆にLUMO 側の障壁を大きくすることで電子が正孔輸送層側へ通り抜け ていかないようにする：この電子の阻止は素子寿命とも深く 関係する. 多くの正孔輸送材料は芳香族アミン系であり, 電 子が注入されると分解する可能性が指摘されている. つま り, ラジカルアニオンが不安定ということで, その注入を阻 止する必要がある. また, 電荷の注入や輸送だけでなく, 電 子と正孔の再結合で生成した励起子（励起状態）を発光層に 閉じ込め効率的に基底状態へ放射遷移させる必要がある。こ の場合, 励起状態のエネルギー準位が重要となる. 蛍光性有 機 $\mathrm{EL}$ 素子の場合は, 発光に寄与する励起状態は一重項励起 状態 $\left(\mathrm{S}_{1}\right)$ であるため, 正孔輸送層や電子輸送層の $\mathrm{S}_{1}$ の工 ネルギー準位が発光層よりも大きいことが必要条件となる.

有機 EL 素子の発光効率としては, 前述した電力効率の他 に電流効率 $(\mathrm{cd} / \mathrm{A})$ と量子効率 $(\%)$ があり，それぞれ使 い分けられている. 発光材料の評価の点では電流効率がよく 用いられ, 動作機構などの物理現象を理解する上では外部量 子効率が適している. 外部量子効率は外部から注入した電子 数に対する発生した光子数を百分率 (\%)で表現するもので, 次式で表現される17).

$$
\eta_{\text {ext }}=\gamma \chi \eta_{P L} \eta_{\text {out }}
$$

ここで, $\gamma$ は電子と正孔の電荷バランス因子, $\chi$ は発光に 寄与する励起状態の生成確率, $\eta_{P L}$ はその励起状態からの発 光量子効率 (PL 量子効率), $\eta_{\text {out }}$ は素子外への光取り出し効 率で, これらを掛け合わせたものが外部量子効率である. 電 荷バランス因子とは, 有機/有機界面の電位障壁を制御する ことで100\%に近い状態を実現することが可能である．ここ で, 理想的な有機 EL 素子を仮定すると,「発光の外部量子 効率」は 5〜 7.5\%の值が導き出される.この值が一般に言 われている蛍光材料での外部量子効率の理論限界值である.

今日まで, 明瞭な界面を持つ多層構造にすることで動作電 圧を低減するとともに電荷の再結合確率を高めることが進め られてきたが，一方では, 界面を乱すことで性能を向上させ る研究もある. Fig. 8 に界面状態の異なる素子構造を定性 的に示す. 古くは, Motrolla の研究グループが Fig. 8(b)の ように正孔輸送層と発光層, あるいは電子輸送層を混合する ことで著しい長寿命化を報告している18)。但し，この場合 は電荷の閉じ込めが不十分になるため, 発光効率が低下して 


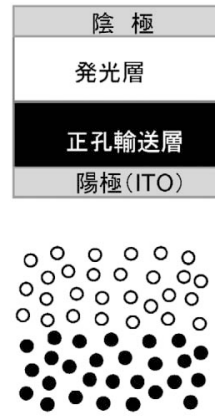

(a) 2層型
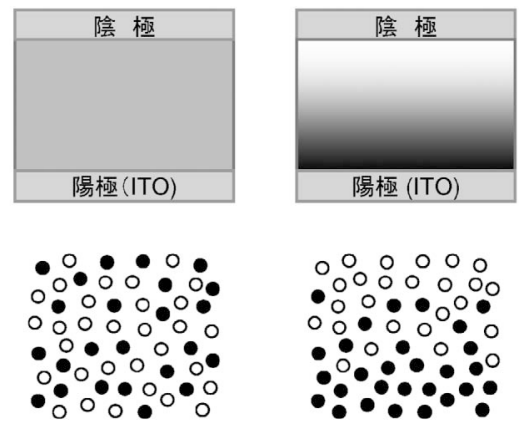

(b) 混合型

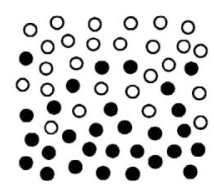

(c) 傾斜混合型
Fig. 8 Interface structures for an two-layer OLED consisting of hole transport material and emitting material.

いる. 発光効率もある程度維持しながら長寿命化ということ で傾斜的に混合する例もある ${ }^{19)}$ 。また，明瞭な 2 層界面は 電荷閉じ込めでは有効であるが，一方では局所的に高電界々 なり, ジュール熱の発生や高電界による化学反応が懸念され る. それ以外に, 界面に蓄積された多量の電荷が励起子と相 互作用し解離（消滅）させる可能性も議論されている。これ は発光効率の低下をもたらすことになる.

今回, 高分子 EL 素子については殆ど触れなかったが，そ の構造は Fig. 2 の 2 層構造に類似している. 正孔輸送層の 替わりに正孔注入層としてPEDOT : PSS を用いることで動 作電圧を低減させている。しかし，このこと自体が種々の問 題を引き起こすことが指摘されている．PEDOT：PSS 中の 硫黄や残留イオンの発光層への拡散, また, 高導電性である ため, この界面での励起状態の消滅がある。この対策とし て，非常に薄いアミン系高分子を中間層 (インターレーヤー) として挿入することで効率の改善と大幅な寿命改善が実現で きる20).

\section{6. おわりに}

本稿では, 有機 $\mathrm{EL}$ 素子の界面に関わる問題, 特に電位障 壁を中心に述べ，その対応策の現状について述べた。しか し，これら界面の現象についてはまだ十分には解明されてい ないのが実情である．有機 EL 素子の性能を究極的なところ まで引き出すには材料開発, 素子構造の最適化に加えて界面
制御が不可欠である．電位障壁の問題の他に，少しだけ触れ た拡散や化学反応の問題, 励起子消減の問題, そのほかに密 着性等もある. 今後, これら有機 ELの界面の問題に界面研 究を専門とする方々が参入されることを期待したい。

[文献〕

1) C. W. Tang, S. A. VanSlyke and C. H. Chen: J. Appl. Phys., 65 (1989) 3610.

2) C. Adachi, S. Tokito, T. Tetsuo and S. Saito: Jpn. J. Appl. Phys., 27 (1998) L713.

3）時任静士, 安達千波矢, 村田英幸: 有機 EL ディスプレイ, オーム社 (2004).

4) B. D'Andrade, Y.-Y. Tsai, C. Lin, P. B. Mackenzie and M. S. Weaver: Information Display, 2/07 (2007) 24.

5) H. Ishii, K. Sugiyama, E. Ito and K. Seki: Adv. Mater., 11 (1999) 605.

6) S. T. Lee, Y. M. Wang, X. Y. Hou and C. W. Tang: Appl. Phys. Lett., 74 (1999) 670.

7) Y. Shirota, Y. Kuwabara, H. Inada, T. Wakimoto, H. Nakada, Y. Yonemoto, S. Kawami and K. Imai: Appl. Phys. Lett., 72 (1998) 2448.

8) L. S. Hung, L. R. Zheng and M. G. Mason: Appl. Phys. Lett., 78 (2001) 673.

9) S. Tokito, K. Noda and Y. Taga: J. Phys. D: Appl. Phys., 29 (1996) 2750.

10) A. Elschner, F. Bruder, H.-W. Heuer, F. Jonas, A. Karbach, S. Kirchmeyer, S. Thurm and R. Wehrmann: Synth. Met., 111 (2000) 139.

11) B. Maenning, M. Pfeiffer, A. Nollau, X. Zhou, K. Leo and P. Simon: Phys. Rev. B, 64 (2001) 195208.

12) T. Wakimoto, Y. Fukuda, K. Nagayama, A. Yokoi, H. Nakada and M. Tsuchida: IEEE Transaction Electron Devices, 44 (1997) 1245.

13) L. S. Hung, C. W. Tang and M. G. Mason: Appl. Phys. Lett., 70 (1997) 152.

14) M. Suzuki, S. Tokito, T. Igarashi, K. Kondo, T. Koyama and T. Yamaguchi: Appl. Phys. Lett., 86 (2005) 103507.

15) J. Kido and T. Matsumoto: Appl. Phys. Lett., 73 (1998) 2866.

16) J. Hung, M. Pfeiffer, A. Werner, J. Blochwitz, K. Leo and S. Y. Liu: Appl. Phys. Lett, 80 (2002) 139.

17) T. Tsutsui: MRS Bulletin, 22 (1997) 39.

18) V.-E. Choog, S. Shi, J. Curless. C.-L. Shieh, H.-C. Lee, J. Shen and J. Yang: Appl. Phys. Lett., 75 (1999) 172.

19) A. B. Chwang, R. C. Kwong and J. Brown: Appl. Phys. Lett., 80 (2002) 725.

20) J.-S. Kim, R. Friend, I. Grizzi and J. H. Burroughes: Appl. Phys. Lett., 87 (2005) 023506. 